\title{
Critical Literature Review on Internal Audit Effectiveness
}

\section{Edward Yeboah}

Department of Accounting and Finance, KNUST School of Business, Kwame Nkrumah University of Science and Technology (KNUST), Kumasi, Ghana

Email: eddie.yeboah401@gmail.com

How to cite this paper: Yeboah, E. (2020). Critical Literature Review on Internal Audit Effectiveness. Open Journal of Business and Management, 8, 1977-1987. https://doi.org/10.4236/ojbm.2020.85121

Received: June 15, 2020

Accepted: August 17, 2020

Published: August 20, 2020

Copyright (c) 2020 by author(s) and Scientific Research Publishing Inc. This work is licensed under the Creative Commons Attribution International License (CC BY 4.0).

http://creativecommons.org/licenses/by/4.0/ (c) (i) Open Access

\begin{abstract}
This paper attempts to critically review literature on internal audit effectiveness. Some empirical findings were selected for the study. It was revealed that studies concentrated on public sector organizations. Also, internal auditors' attributes were identified as the key for the measurement of internal audit effectiveness and that the relationship of internal auditors and external auditors, chief audit executives and senior management play a pivotal role in internal audit effectiveness. It is recommended that research in internal audit effectiveness should encapsulate empirical studies in the private sector organizations; comparative analysis of private and public sector organizations; attributes of internal auditors as the core measurement; and the relationship and/or causality of management support and internal audit effectiveness. Additionally, relationship of internal auditors with others including external auditors, chief audit executives and senior management should be emerging areas of research in internal audit effectiveness.
\end{abstract}

\section{Keywords}

Internal Audit Effectiveness, Internal Auditors' Attributes, Management Support, Internal Auditing

\section{Introduction}

Internal audit is very relevant to ensure the efficient utilization of resources, control misappropriation and combat fraud and misapplication of the resources of a company (Badara \& Saidin, 2014). Internal auditing applies principles in an organization to ensure efficiency in the growth and development of a company leading to sustainable financial conditions. Alzeban and Gwilliam (2014) believe that failure in an organization is the result of poor implementation of internal 
audit practices. Due to the overwhelming recognition of internal auditing in corporate governance, the measurement of internal audit effectiveness has attracted academic studies. It is therefore imperative to undertake a critical review of literature on internal audit effectiveness. This will not only make value additions to the growing literature on internal auditing but also bring to the fore the theoretical and/or knowledge gaps to form the basis of further research into the field.

Badara \& Saidin (2014) state that internal audit effectiveness has become a fruitful topic over the decade. This is because of the important roles play by the internal auditors in organizational survival and achievement. They averred that most of the organizations, whether public or private, have established internal audit department with the mind of enjoying the benefit behind the internal audit service. Myriad of empirical findings point to variables affecting internal audit effectiveness. These studies showed avalanche of differences in the measurement and approaches of internal audit effectiveness. There are also theoretical differences by researchers in analyzing internal audit effectiveness and there seems to be lack of consensus in the measuring variables of internal audit effectiveness.

Whilst some studies adopted the International Standards for Professional Practice of Internal Auditing (ISPPIA) as the framework for the measurement of internal audit effectiveness (Al-Twaijry, Brierley, \& Gwilliam, 2003), other researchers developed their own models in the measurement of variables (Mihret \& Yismaw, 2007; Arena \& Azzone, 2009). In contributing to measures to address the lack of consensus on the theoretical framework of internal auditing, Endaga \& Hanefah (2013) asserted that the agency theory, institutional theory and communication theory could serve as the approach to build a theoretical framework of internal audit framework.

The main objective of this study is to determine the variables for the measurement of internal audit effectiveness. The study involves a review of related literature and analysis and discussion of findings on the variables for measuring internal audit effectiveness.

\section{Selected Empirical Findings}

Al-Twaijry et al. (2003) use institutional theory to interpret the results of two questionnaires and research interviews concerned with internal audit in the Saudi Arabian corporate sector. The results show that internal audit is not well developed. Where it does exist, it operates in departments that are inadequately resourced, lack qualified staff, have restrictions on their degree of independence, concentrate on compliance audit rather than performance audit, and where internal auditors are not accepted by management and auditees. Using institutional theory, the authors suggested that the state should play a more coercive role by encouraging organizations to establish internal audit departments and organize their activities in the manner specified in internal audit standards.

Based upon a case study of a large public sector higher educational institution 
in Ethiopia, Mihret \& Yismaw (2007) examined how internal audit quality, management support, organizational setting, auditee attributes, and the interplay among these factors, influence internal audit effectiveness. The findings of the study highlight that internal audit effectiveness is strongly influenced by internal audit quality and management support, whereas organizational setting and auditee attributes do not have a strong impact on audit effectiveness.

Cohen \& Sayag (2010) exploratory study was to build a conceptual understanding of the effectiveness of internal audit in organizations. They developed a scale to measure the effectiveness of internal audit and a model of its determinants. One hundred and eight Israeli organizations that employ internal audit participated in the study (a 37\% response rate). Data on the effectiveness of internal audit were collected from the organizations' general managers and data on the determinants from their internal auditors. The findings revealed good psychometric properties for the scale developed in this study. The correlation and regression analyses showed support from top management to be the main determinant of internal audit effectiveness, with some effect also found for the organizational independence of internal audit. The effect of the predictors was consistent between the public and private sectors. The research model explained a large amount of variance of internal audit effectiveness.

Hailemariam (2014) investigated on the determinants of internal audit effectiveness in the selected Ethiopian public sector offices. The investigation was focused on 15 purposely selected public sector offices that are expected to represent all other sectors. The management teams and the internal auditors of the selected public sector office were the source for the required data to the researcher through the questionnaires administered. In addition, the finding of this study was to show the direct relation effects of management perception, management support, organizational independence of internal auditors, adequate and competent internal auditor's staff and the presence of approved internal audit charter with the internal audit effectiveness on the public sector management. According to the regression output the management support, the existence of adequate and competent internal audit staff, and the availability of approved internal audit charter were contributed for the internal audit effectiveness in the public sector significantly and positively. The remaining two variable; the managements perception for the internal audit value and the organizational independent of internal auditors were positively related with the internal audit effectiveness but their contribution for the internal audit effectiveness were statistically not significance. All of these five independent variables made $55.10 \%$ of the contributions for internal audit effectiveness in the public sector offices.

Baharud-din, Shokiyah and Ibrahim (2014) investigated the factors that contribute to the effectiveness of internal audit in the Malaysian public sector. It was to determine the auditors' perception toward the effectiveness of internal audit work, influenced by the quality of audit work in order to perform in an effective 
manner as control instrument in public financial management. It also aimed to determine the relationship between factors that contribute to the effectiveness of internal audit works in promoting better transparency and integrity of public management. The scope of this study covered the internal auditors that work in the ministries in Putrajaya. This study employed a cross sectional survey to investigate the effectiveness of internal audit. Several statistical techniques such as the descriptive statistic, correlation and regression analysis were used to analyse the data from the survey. The result of the study showed that there were significant positive relationships among the factors analyzed in the study such as auditor competency, auditors' independence and objectivity and management support to the effectiveness of internal audit. Thus, the effectiveness of internal audit will depend strongly on the attributes of the factors analyzed in this study.

Alzeban \& Gwilliam (2014) assessed factors influencing internal audit effectiveness (IAE) in Saudi Arabia. Data were obtained from 203 managers and 239 internal auditors from 79 Saudi Arabian public sector organizations. Multiple regression analysis examines the association between IAE and five principal factors. Results suggest that management support for IAE drives perceived effectiveness of the internal audit function from both management's and the internal auditors' perspective. Management support is linked to hiring trained and experienced staff, providing sufficient resources, enhancing the relationship with external auditors, and having an independent internal audit department. Saudi Arabia is representative of many developed and developing environments, and its recent tradition of governance and audit is mirrored in countries worldwide. Moreover, its specific cultural traditions involving clan and tribal allegiances, and pervasive and core religious beliefs, characterize the GCC countries, the Arab World generally, and indeed, many other developing countries, irrespective of wealth. Thus, links between management support and internal audit effectiveness are likely generalizable beyond the Saudi public sector context.

Mustika (2015) tested the factors that influence the internal audit effectiveness, including internal auditor competencies, internal auditor independence, auditee support to internal audit activity, and the internal and external auditor relationship. Using the internal auditor inspectorate in Java Province, Indonesia, the researcher found that the internal audit effectiveness can be attained through increase internal audit competence, independence and strong relationship between internal and external auditor. However, this study found that auditee support has no effect on internal audit effectiveness.

Endaya and Hanefah (2016), investigated the direct relationship between internal auditors' characteristics and internal audit effectiveness, and the moderating effect of senior management support. Standard multiple regression and moderated multiple regression were applied, and the data were collected from 114 members of Libyan Association of Accountants and Auditors by using personally administered questionnaire. The findings revealed that internal auditors' characteristics have a significant impact on internal audit effectiveness and se- 
nior management support has a moderating effect. The findings would encourage Libyan organizations to concentrate on the issue of internal audit effectiveness, and will strengthen the capacity of internal auditing in public organizations.

Dellai \& Omri (2016) examined factors influencing internal audit effectiveness in the Tunisian context. Data was collected from responses to a questionnaire addressed to Chief Audit Executives of 148 Tunisian organizations. Multiple regression analysis examines the association between the effectiveness of the internal audit function and six principal factors. Results revealed that the effectiveness of internal auditing is influenced by: the independence of internal audit, the objectivity of internal auditors, the management support for internal audit, the use of internal audit function as a management training ground, and the sector of organization. The study provided useful information to practitioners and academics who are interested to identify the determinants of internal auditing effectiveness in developing countries.

Tackie, Marfo-Yiadom and Achina (2016) examined the determinants of internal audit effectiveness in decentralized local government administrative systems of Ghana. Ghana's local government system is structured into Metropolitan, Municipal, and District Assemblies (MMDAs). For the purpose of the study, the researchers focused on the Ashanti region of Ghana which has the highest number of MMDAs. The motivation for the study was derived from the increased interest in the internal audits of local government units. Using a descriptive survey, the data gathered, through the use of questionnaire, revealed that majority of the internal audit staff of MMDAs in the Ashanti Region of Ghana possess the requisite professional proficiency. Contrary to the perception that audit quality in the public sector is usually compromised, the study revealed that there exists high quality of audit work due to compliance with the international standards on auditing and local audit legislations. Professional proficiency, organizational independence, and career advancement were found to have statistically significant positive relationship with internal audit effectiveness, whiles top management support was found to have no effect on internal audit effectiveness.

Chevers, Lawrence, Laidlaw \& Nicholson (2016) investigated the factors that influence the effectiveness of the internal audit function in Jamaican commercial banks. The study found that the quality of audit investigation, organizational independence, professional proficiencies and management support have a significant impact on internal audit effectiveness. They concluded that it is imperative for stakeholders and policy makers to understand the important role internal audit plays in the financial viability and financial health of any financial institution.

Lenz, Sarens and Hoos (2017) examined the relationship between Chief Audit Executives (CAEs) and Senior Management (SM) and its relationship with internal audit (IA) effectiveness. The study revealed differences between more and less effective IA functions and offers explanations by studying organizational, 
personal, and interpersonal factors within the German corporate governance context. The findings showed that the pattern of interaction between CAEs and SM is a key determinant of IA effectiveness. This study highlights the danger of viewing customer satisfaction as the key measure of IA effectiveness since in practice expectations can vary significantly and as sometimes very little may be demanded. Moreover, CAEs typically adjust to expectations, upward and downward. CAEs can drive the agenda as well. When it comes to personality factors, "Finger-feeling" and swimming in the organization characterize the successful internal auditor. IA designations for CAEs were not found to be of added value. At the organizational level, the findings show that companies that are considered as "hidden champions" demand and benefit from effective IA practices.

Shamki \& Alhajri (2017) examined the extent internal audit effectiveness could be influenced by selected factors namely internal audit scope, internal auditor's experience and senior management's response in the Omani public sector. Employing questionnaire including four sections with 48 questions for responds of 45 managers and 163 employees in Public Authority for Social Insurance (PASI) in the Sultanate of Oman, descriptive analysis, correlation analysis, and multiple regressions were employed to examine the relationships among the study's variables. The study found that a significant relationship between internal audit effectiveness and its scope and auditors' experience in the employees' sample while they were insignificant in the managers' sample. Finally, it is found that there is insignificant relationship between internal audit effectiveness and senior management's response. Based on the findings, an awareness has to be maximized on employees to better cooperate with internal audit staff to improve the applications of internal audit standards. Managers are well interested in organization's activities and performance depending on the internal audit findings and observations. The board of directors has to take in its considerations the reasons of these insignificant results if the reasons are not related to the small size of the managers' sample. The study's contribution is to provide evidence regarding the influence of three mentioned factors on the internal audit effectiveness in public sector.

Bednarek (2017) sought to understand the factors that affect internal audit effectiveness. Based on the survey from 342 organizations in Poland it was found that the internal audit effectiveness is affected by: 1) the characteristics of the internal audit, 2) audit activity, and 3) inter-organizational relationships. The effectiveness increases when the age of the internal audit grows, performing audit engagements is regularly monitored, the results of measuring the audit performance and self-assessment are employed for introducing changes, audit committee indicates significant risks and sets priorities for the annual and strategic audit plans, and commissioned audits do not exceed $20 \%$ of the work of the internal audit.

Rudhani, Vokshi \& Hashani (2017) asserted that since audit has a great im- 
portance in preventing, consulting and finding cases of funds misuse, it was thought of analyzing the factors that contribute to increasing the efficiency of internal audit in the public sector which would help to set proper and more transparent governance of public financial resources. They therefore undertook a study that investigated the relationship between effectiveness and contributing factors. The data for the study were collected through an online questionnaire and direct hand-outs of such. The results of the empirical analysis proved that effectiveness has a positive relationship with internal audit quality, the competence of the internal audit team, the independence of internal audit, as well as with the support of internal audit from the management. Moreover, it was confirmed that audit quality is the fundamental element of the effectiveness of internal audit since it was among the most influential factors in the sample.

Bednarek (2018), undertook a study to understand the factors that affect internal audit effectiveness. Based on the survey from 342 organizations in Poland it was found that the internal audit effectiveness is affected by: 1) the characteristics of the internal audit, 2) audit activity, and 3) inter-organizational relationships. The effectiveness increases when the age of the internal audit grows, performing audit engagements is regularly monitored, the results of measuring the audit performance and self-assessment are employed for introducing changes, audit committee indicates significant risks and sets priorities for the annual and strategic audit plans, and commissioned audits do not exceed $20 \%$ of the work of the internal audit.

Musah, Gapketor, \& Anokye (2018) examined factors that determine internal audit effectiveness among SOEs in Ghana. The study was conducted in response to various scandals among Ghanaian SOEs and the lack of empirical studies on determinants of internal audit effectiveness that can deal with these problems. The study specifically examined the respondent's perception about the impact of factors such as; competence of internal audit unit, size of internal audit unit, relation between internal and external auditors, management support for internal audit function, and independence of internal audit unit on internal audit effectiveness among SOEs in Ghana. They surveyed internal auditors, accountants and management of these sampled SOEs in Ghana. The results of the study showed that management support for internal audit function is the most significant determinants of internal audit effectiveness. The study also revealed that size of internal audit unit, competence of internal audit staff, independence of internal audit unit as well as good relationship between internal and external auditors were significant determinants of internal audit effectiveness.

\section{Discussions}

The key findings from the above empirical studies include:

1) Concentration on public sector organizations;

2) Internal audit attributes as measurement of internal audit effectiveness;

3) Differences in opinion in relation to management support as a factor in 
measuring internal audit effectiveness and;

4) Relationship of internal auditors and others such as external auditors, chief audit executives and senior management as influential factors of internal audit effectiveness.

Whilst Baharud-din et al. (2014) works focused on Malaysian public sector, specifically in the ministries in Putrajaya, Tackie et al. (2016) concentrated on decentralized local government administrative systems of Ghana. Ghana's local government system is structured into Metropolitan, Municipal, and District Assemblies (MMDAs) and the researchers focused on the Ashanti region of Ghana which has the highest number of MMDAs. Endaya and Hanefah (2016) on their part collected data from Libyan Association of Accountants and Auditors. Dellai \& Omri (2016) works were in the Tunisian context and data was collected from responses to a questionnaire addressed to Chief Audit Executives of Tunisian organizations. Mustika (2015) on his part, collected data from the internal auditor inspectorate in Java Province, Indonesia and Alzeban \& Gwilliam (2014) obtained data from 79 Saudi Arabian public sector organizations. Shamki \& Alhajri (2017) collected data for their work in the Omani public sector, whilst Bednarek (2017) gathered data based on the survey of organizations in Poland.

Hailemariam (2014) work was on Ethiopian public sector offices. The work was focused on 15 purposely selected public sector offices that are expected to represent all other sectors. Musah et al. (2018) concentrated on SOEs in Ghana. This was in response to various scandals among Ghanaian SOEs and the lack of empirical studies on determinants of internal audit effectiveness that can deal with these problems. Mihret \& Yismaw (2007) works focus on a large public sector higher educational institution in Ethiopia. However, some works factored in private sector organizations (Al-Twaijry et al., 2003; Cohen \& Sayag, 2010; Chevers et al., 2016).

Perspectives from private sector organizations are less dominance in relation to public sector organizations. It will be worthwhile for researchers to not only look at the internal auditing effectiveness in the private sectors but also undertake comparative studies of both private and public sectors of countries. With the increasingly recognition of the private sector in the economies of emerging and developed countries, the need to focus attention of internal audit effectiveness in the private sectors of economies cannot not gainsaid.

The factors of internal audit effectiveness identified were mostly attributes of internal auditors. These were auditors' characteristics including auditor competency; auditors' independence; objectivity; professional proficiency; career advancement; and auditors' experience (Baharud-din et al. 2014; Endaya \& Hanefah, 2016; Dellai \& Omri, 2016; Tackie et al., 2016; Mustika, 2015; Shamki \& Alhajri, 2017; Bednarek, 2017; Rudhani et al., 2017; Hailemariam, 2014; Chevers et al., 2016; Bednarek, 2018; Musah et al., 2018). Attention of researchers could be deepened in the attributes of internal auditors as catalyst of internal audit effectiveness and understanding the dynamism of audit problems. 
The researchers differ in the shade of opinion in relation to management support as a variable in influencing internal audit effectiveness. Mihret \& Yismaw (2007); Cohen \& Sayag (2010); Hailemariam (2014); Baharud-din et al. (2014); Chevers et al. (2016); Endaya and Hanefah (2016); Dellai \& Omri (2016); Alzeban \& Gwilliam (2014); Rudhani et al. (2017); and Musah et al. (2018) identified management support for internal auditors as a factor in influencing internal audit effectiveness. On the other hand, Tackie et al. (2016) and Mustika (2015) found management support as having no effect on internal audit effectiveness. This requires further research to broaden knowledge on the relationship and /or causality of management support and internal audit effectiveness.

Relationships between internal auditors and external auditors; between internal auditors and chief audit executives and senior management; internal auditors and inter-organisational relationships are research areas that need further studies. This can be inferred from the works of Lenz et al. (2017), Mustika (2015), Bednarek (2018) and Musah et al. (2018).

\section{Conclusion and Recommendations}

The evaluation of the above empirical findings points to conclusions including public organizations dominance of studies; internal auditors' attributes; and the role of relationships with management and external auditors in internal audit effectiveness. These highlight knowledge gaps which will provide opportunities for further research. Additionally, such evaluation will not only be justification for further literature reviews but also identify and develop research questions and hypotheses. It is therefore recommended that future and further research in internal audit effectiveness should encapsulate the following factors.

Empirical studies in the private sector organizations. The pivotal role of the private sector in the economies of emerging and developed economies make this demand on researchers worthwhile. This is against the backdrop of inadequate development of internal auditing in the corporate sector as pointed out by Al-Twaijry et al. (2003).

Comparative analysis of internal audit effectiveness in private and public sector organizations. Such studies will add further impetus of the variables of measurement in internal audit effectiveness and deepen understanding about the workability of recommendations in the improvement of auditing in organizations. Additionally, the test of consistency in predictors of internal audit effectiveness can be conducted in both private and public sector organizations. This can broaden the understanding of internal audit effectiveness in organizations as attempted by Cohen \& Sayag (2010).

Attributes of internal auditors as the core of internal audit effectiveness: This will not only help in efficiency in resource allocations toward enhanced internal audit effectiveness but also broaden the understanding of audit problems. There seems to be lack of consensus on the measuring variables of internal audit effectiveness (Endaga \& Hanefah, 2013). The concentration on internal audit charac- 
teristics and attributes will help minimize this problem of internal audit effectiveness.

Relationship andlor causality of management support and internal audit effectiveness: Reasons for indifference in consensus building of the measuring variable of management support in internal audit effectiveness could be unearthed. The causality and other moderating and/or controlling effects of management support on internal audit effectiveness could be tested.

Relationship of internal auditors with others including external auditors, chief audit executives and senior management. This will bring to focus the need for relationship building and the role of inter-organizational relationships in making internal auditing effectiveness in organizations. Internal auditing cannot be effective without cordial and strong relationship between the internal auditor and others including external auditors, chief audit executives and senior management.

\section{Conflicts of Interest}

The author declares no conflicts of interest regarding the publication of this paper.

\section{References}

Al-Twaijry, A. A., Brierley, J. A., \& Gwilliam, D. R. (2003). The Development of Internal Audit in Saudi Arabia: An Institutional Theory Perspective. Critical Perspectives on Accounting, 14, 507-531. https://doi.org/10.1016/S1045-2354(02)00158-2

Alzeban, A., \& Gwilliam, D. (2014). Factors Affecting the Internal Audit Effectiveness: A Survey of the Saudi Public Sector. Journal of International Accounting, Auditing and Taxation, 23, 74-86. https://doi.org/10.1016/j.intaccaudtax.2014.06.001

Arena, M., \& Azzone, G. (2009). Internal Audit Effectiveness: Relevant Drivers of Auditees' Satisfaction. International Journal of Auditing, 13, 43-60. https://doi.org/10.1111/j.1099-1123.2008.00392.x

Badara, M. A. S., \& Saidin, S. Z. (2014). Empirical Evidence of Antecedents of Internal Audit Effectiveness from Nigerian Perspective. Middle-East Journal of Scientific Research, 19, 460-471.

Baharud-din, Z., Shokiyah, A., \& Ibrahim, M. S. (2014). Factors That Contribute to the Effectiveness of Internal Audit in Public Sector. International Proceedings of Economics Development and Research, 70, 126.

Bednarek, P. (2017). The Relationship between Organisational Attributes and Internal Audit Effectiveness. Research Papers of the Wroclaw University of Economics/Prace Naukowe Uniwersytetu Ekonomicznego we Wroclawiu, No. 474.

Bednarek, P. (2018). Factors Affecting the Internal Audit Effectiveness: A Survey of the Polish Private and Public Sectors. In T. Dudycz, G. Osbert-Pociecha, B. Brycz (Eds.), Efficiency in Business and Economics (pp. 1-16). Cham: Springer. https://doi.org/10.1007/978-3-319-68285-3 1

Chevers, D., Lawrence, D., Laidlaw, A., \& Nicholson, D. (2016). The Effectiveness of Internal Audit in Jamaican Commercial Banks. Accounting and Management Information Systems, 15, 522. 
Cohen, A., \& Sayag, G. (2010). The Effectiveness of Internal Auditing: An Empirical Examination of Its Determinants in Israeli Organisations. Australian Accounting Review, 20, 296-307. https://doi.org/10.1111/j.1835-2561.2010.00092.x

Dellai, H., \& Omri, M. A. B. (2016). Factors Affecting the Internal Audit Effectiveness in Tunisian Organizations. Research Journal of Finance and Accounting, 7, 208-221.

Endaya, K. A., \& Hanefah, M. M. (2016). Internal Auditor Characteristics, Internal Audit Effectiveness, and Moderating Effect of Senior Management. Journal of Economic and Administrative Sciences, 32, 160-176. https://doi.org/10.1108/JEAS-07-2015-0023

Hailemariam, S. (2014). Determinants of Internal Audit Effectiveness in the Public Sector, Case Study in Selected Ethiopian Public Sector Offices. Doctoral Dissertation, Jimma University, Jimma.

Lenz, R., Sarens, G., \& Hoos, F. (2017). Internal Audit Effectiveness: Multiple Case Study Research Involving Chief Audit Executives and Senior Management. EDPACS, 55, 1-17. https://doi.org/10.1080/07366981.2017.1278980

Mihret, D. G., \& Yismaw, A. W. (2007). Internal Audit Effectiveness: An Ethiopian Public Sector Case Study. Managerial Auditing Journal, 22, 470-484.

Musah, A., Gapketor, E. D., \& Anokye, F. K. (2018). Determinants of Internal Audit Effectiveness in State-Owned Enterprises (SOEs) in Ghana. The Journal of Accounting and Management, 8,52 .

Mustika, A. C. (2015). Factors Affecting the Internal Audit Effectiveness. Jurnal Akuntansi dan Auditing, 12, 89-109.

Rudhani, L. H., Vokshi, N. B., \& Hashani, S. (2017). Factors Contributing to the Effectiveness of Internal Audit: Case Study of Internal Audit in the Public Sector in Kosovo. Journal of Accounting, Finance and Auditing Studies, 3, 91-108.

Shamki, D., \& Alhajri, T. A. (2017). Factors Influence Internal Audit Effectiveness. International Journal of Business and Management, 12, 143-154. https://doi.org/10.5539/ijbm.v12n10p143

Tackie, G., Marfo-Yiadom, E., \& Achina, S. O. (2016). Determinants of Internal Audit Effectiveness in Decentralized Local Government Administrative Systems. International Journal of Business and Management, 11, 184-195. https://doi.org/10.5539/ijbm.v11n11p184 